\title{
Application of Quality Function Development method to establish application of new product development information system
}

\author{
Chien-Wen Hung 1,* \\ ${ }^{1}$ Department of Information Management, Chia-Nan University of Pharmacy \& Science \\ 1 cwhong@mail.cnu.edu.tw * \\ * Corresponding author
}

(Received April 24, 2021 Accepted April 24, 2021, Available online April 25, 2021)

\begin{abstract}
In the process of new product development, the customer's feeling is usually fuzzy phenomenon, how to evaluate various factors is to test the developer's intelligence, this study takes the new product development process as the research object, and applies the Quality Function expansion (QFD) method to establish a decision support system with fuzzy processing ability. In this study, the first development of quality function expansion (QFD) applied to Customer voice collection and analysis and conversion to product specifications. Then, the integration of fuzzy theory and the provision of different commodity development solutions as the best choice for products.
\end{abstract}

Keywords: QFD; New Products Development; Fuzzy Method; Decision Support System;

\section{Introduction}

In General, the enterprises at the time of the development of new products must go through different stages, including the development of new product development strategies [1], combined with the various departments within the organization brings together resources and integration of different technologies and manpower.

What the enterprise to develop new products: we can go from six policy basis to illustrate [2]:

1) The development of new products is one of the sources of competitive advantage.

2) New product development is to create advantage or opportunity to reverse the policy direction.

3) The development of new products can have a long-term return on investment.

4) New products are the main business profit.

5) New products to improve the production and the job of idle resources.

6) New product marketing the brand value of defending the forward slash role to play.

Therefore, in this study, we propose a New product development model that is based on the Quality Function Deployment. As shown in Figure 1 Furthermore, to demonstrate the proposed approach, the Beverage market is chosen as the empirical sample for this study. 


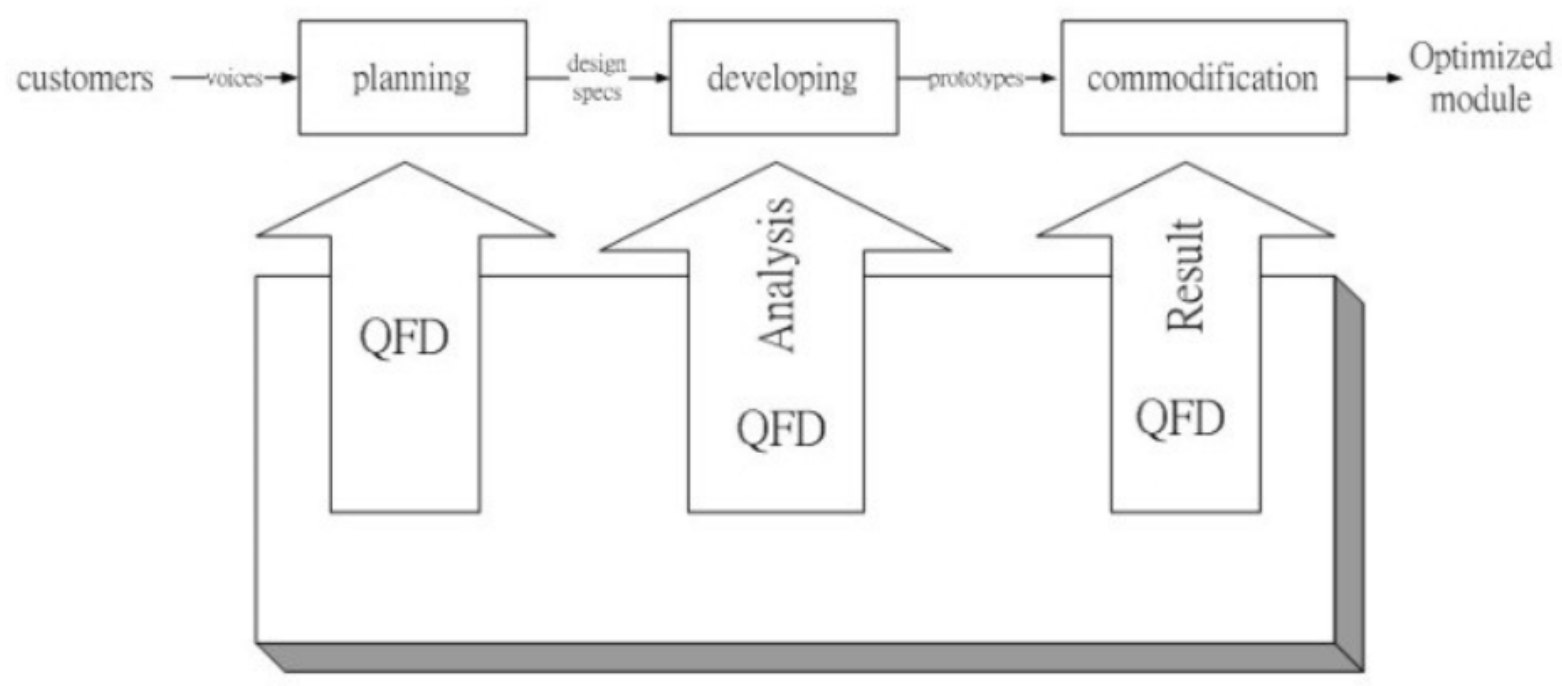

Fig. 1. The framework of the proposed mode

\section{Background}

\subsection{Quality Function Deployment}

Quality Function Deployment, has success to using in all industry, and effectiveness good, including Japan of stone bridge tire, and Kobe shipyard, and Toyota car, United States Ford car also in 1983 introduced QFD, Taiwan in 1988 began promotion, pursuant to customer demand, conversion for commodity of quality design, in conversion process in the must through enterprise internal of market marketing, and commodity development, and quality design and the production manufacturing related sector of integration and the coordination, QFD helps enterprises across sectors, to communicate and share information such as performance improvement. At the time of implementation of quality function deployment, must rely on the quality of housing (House of Quality, HOQ) such interface tool-assisted, House of quality content schema [5]. Quality House of basic calculation rules, must be determined by characteristics of customer needs into executable projects, it must be important to customer needs, giving adequate weight. From the House of quality structure to seek customers ' needs (Voice of Customer), quality analysis and to effectively control VOC of planning, and its solution methods due consideration of different and different results [6].

\subsection{New Product Development Information System}

1970, Donvan and Madnick new product development information system for the type of proposed two types of arguments [7]. In addition, Garnto with Watson for the past four new product development systems for detailed investigation, and generally these four systems are summarized as a regular use of the nature of new product development systems [8]. Typically train invoicing system (Train Dispatching System), automatic information management system (AIMS). And addressing specific issues of the new product development system, a representative of the United States Coca-Cola price support system (Pricing Model), M \& A support system (Acquisition Model). The study found that the above two types of new products to the development of information systems there are some differences in the existence of the phenomenon, as shown in Table 1.

Table. 1. Standing-NPD and Special-NPD

\begin{tabular}{|c|c|c|c|}
\hline Property classification & Detail description & Standing-NPD & Special-NPD \\
\hline $\begin{array}{c}\text { Decision making types } \\
\text { describe }\end{array}$ & Frequency of occurrence & Many & Not Many \\
\cline { 2 - 4 } & Prior data often little & Many & Not Many \\
\hline
\end{tabular}




\begin{tabular}{|c|c|c|c|}
\hline & $\begin{array}{l}\text { Continuation of the } \\
\text { problem of how long }\end{array}$ & Long & Short \\
\hline & $\begin{array}{c}\text { System of fast-growing } \\
\text { demand low high }\end{array}$ & Low & High \\
\hline \multirow[t]{2}{*}{$\begin{array}{c}\text { Decision target usage } \\
\text { describes }\end{array}$} & $\begin{array}{c}\text { Using the decision target } \\
\text { size }\end{array}$ & Many & Not Many \\
\hline & $\begin{array}{l}\text { Support of fast-growing } \\
\text { demand low high }\end{array}$ & Low & High \\
\hline \multirow{4}{*}{$\begin{array}{c}\text { System development of } \\
\text { data describes }\end{array}$} & Data detail levels & High & Low \\
\hline & Data of the correct level & High & Low \\
\hline & $\begin{array}{l}\text { Terminal user interface } \\
\text { changes }\end{array}$ & Low & High \\
\hline & $\begin{array}{l}\text { Length of system } \\
\text { development }\end{array}$ & Long & Short \\
\hline
\end{tabular}

\section{Case Study}

\subsection{Quality House}

The basic algorithm is the quality of housing, by the customer's requirements into executable technical characteristics, and this usually involves not only a customer's needs. Thus, different customer needs must be given according to their degree of importance of the proper weight. In the house of quality of structure, when the VOC obtained after the quality of analysis and planning in order to effectively control VOC (Voice of the Customer), will further seek more of the weight of the VOC, and its solution method is also considered different factor

In this paper, the gap between expectations and perception and then multiplied by the customer's expectations for this project to measure the customer requirements for product quality, an important degree to overcome the gap in the theory of quantitative formula, the formula is as follows : $W_{v o c} \frac{3}{i}=\left(E_{i}-S_{i}\right) \cdot E_{i}$

$W_{v o c} \frac{3}{i}:$ First $i$ items important to the quality of customer requirements evaluation weight value

$E_{i}:$ Customer quality expectations of the i-th item

$S_{i}:$ Customer demand for the $\mathrm{i}$-th item attribute satisfaction

Through which two indicators to assess, decide the priority of quality factors. Sorting through the quality characteristics of the value assessment method produces the original value, the original value is converted to the original weight, and then to the original weight divided by the sum of the original priority, you can find standard weights.

\subsection{Quality characteristics sort assessment method}

Using the degree of importance and satisfaction of a claim to measure quality items heavier. Quality Characteristics of sorting through the assessment process is recycled after Questionnaire (object questionnaire is 20-50 year-old student and worker groups of ethnic-based), the data collected do the conversion to the original degree of importance and satisfaction each Save to 3 as a new assessment standard value, and then be ranked. Then calculate the difference between attitudes and satisfaction index. 
Attitude is the satisfaction of both service quality factors after the conversion degree of importance and satisfaction with the product obtained by multiplying.

Product differentiation index is the latter two elements of quality of service after the conversion degree of importance and satisfaction rankings subtract the resulting difference. Thus through two indicators to assess, decide the priority of quality factors. So use a sorting feature value quality assessment method produced as an evaluation index of the original value, and be standardized. Standardized methods for finding the weight of the original priority will be converted to the original weight (in reverse order), followed by each of the original weight divided by the sum of the original priority, you can find standardized weights.

\subsection{New product development system}

The design of new product development information systems, including databases and libraries, and a complex pattern system software to link users and other units. Software system includes three features: Database Management System, DBMS, Model Base Management System, MBMS and management information systems and software between the user interface and communication. QFD system is mainly to determine the client messages sent from computers to analyze and generate a structured search statements and normalization module generates the final result of discrimination and pass information back to the system for matching properties of new product development.

\subsection{Some Common Mistakes}

P1, P2, P3, respectively, for the experimental samples P1, experimental samples P2, P3 of the experimental sample fuzzy comprehensive evaluation result of the operation, the results show that $\mathrm{P} 3>\mathrm{P} 1>\mathrm{P} 2$, the meaning of the QFD method is through the re-designed shape of the experimental irrespective of sample $\mathrm{P} 3$ in maneuverability, comfort, good looks and practicality to the subject's feelings at all than the original product (experimental sample P2) increased. The magnitude of the growth In order to rival and even surpass (experimental sample P1), shows the quality function deployment method also applies to product form stage of the guidance and help, and indeed the results obtained for the majority of users can be accepted by this phenomenon for product sales profit or degree may be able to help somewhat.

\section{Conclusion}

In the new product development decision-making process, usually including a demand for new products (Need Recognition), new product information to collect (Information Search), the feasibility of program evaluation (Evaluation), program selection (Choice) and the final program (Outcome) steps. The new product before the final selection will be opened in accordance with different engines have different assessment criteria, and in the implementation of an information program cannot solve the problem, search information to the outside world for the action, until a feasible plan to obtain enough selection so far.

Therefore, this face of new product development when market conditions do not quite understand, by QFD methods of the requirement statements, the use of QFDexpressions of the principle of seeking new product design and calculate the degree of fit market demand, in order to provide the most appropriate market new product selection. Content in the product information section, in order to make efficient use of the product database can be more enhanced information system designed to take in the development of an open information architecture, through the network, database manager, can update the database of product information, which decision support systems will enable new product of inference, have not the same as the most suitable product mix.

In this paper, Beverage products as an example, due to the high volatility of new products, so when designing the information system for the ambiguity function of the set, the database will change as the 
product may change. As the Beverage market will be the mainstream of change, and produce the same changes. This type of new product development needs the service into a physical store, and new product development, the concept of decision support systems to increase the success of the enterprise market with profit results.

\section{References}

[1] Cooper R.G., and Edgett S.J.(2003), Research Technology Management, 46(3), May/Jun, pp.48-58.

[2] David Dreyfus, and Bala Iyer. (2008), Managing architectural emergence: A conceptual model and simulation, Decision Support Systems, 46(1), PP. 115-127.

[3] Goepp V., Kiefer F., and Avila O.(2008), Information system design and integrated enterprise modelling through a key-problem framework, Computers in Industry, 59(7),PP.660-671.

[4] Hafeez K., Malak N., and Zhang Y.B.(2007), Outsourcing non-core assets and competencies of a firm using analytic hierarchy process, Computers \& Operations Research, 34(12),PP. 3592-3608.

[5] Katav Tali, Liu LinShu, Traitel Tamar, Goldbart Riki, Wolfson Marina, and Kost Joseph.(2008) , Modified pectin-based carrier for gene delivery: Cellular barriers in gene delivery course, Journal of Controlled Release, 130(2), PP. 183-191.

[6] Saad Inès, and Chakhar Salem.(2009), A decision support for identifying crucial knowledge requiring capitalizing operation, European Journal of Operational Research, 195(3), PP. 889-904.

[7] Valls Aida, Batet Montserrat, and López Eva M..(2009), Using expert's rules as background knowledge in the ClusDM methodology, European Journal of Operational Research, 195(3),PP. 864-875.

[8] Yoon Byungun.(2008), On the development of a technology intelligence tool for identifying technology opportunity, Expert Systems with Applications, 35(1-2),PP. 124-135.

[9] Zadeh L. A.(1975), The Concept of a Linguistic Variable and its Application to Approximate Reasoning, I, Information Science, 8, pp.199-251.

[10]Zha Xuan F., Sriram Ram D., Fernandez Marco G., and Mistree Farrokh.(2008), Knowledge-intensive collaborative decision support for design processes: A hybrid decision support model and agent, Computers in Industry, 59(9), PP. 905-922 